\title{
Clinical and Demographic Characteristics on Admission and Their Prognostic Value at Discharge in 529 Consecutive COVID-19 Patients in Santiago, Chile
}

Cesar Maquilon Ortiz ${ }^{1, *}$, Jonas Alberto Gongora ${ }^{2}$, Monica Antolini Toledo ${ }^{1}$, Nicolas Fernando Valdes ${ }^{3}$, Angela Benavente ${ }^{4}$, Maria Gabriela Bofill ${ }^{4}$, Macarena Urra ${ }^{4}$, Diego Rojas Carvajal ${ }^{4}$, Javiera Huidobro Navarro ${ }^{4}$, Bernardita Alvarado Breton ${ }^{5}$, Maria Carolina Asenjo ${ }^{5}$, Cherie Gutierrez Rojas ${ }^{5}$, Jose Gajardo ${ }^{2}$, Patricia Cisternas ${ }^{6}$, Guillermo Garcia ${ }^{7}$, Juan Pablo Peralta ${ }^{2}$, Lenny Loor Garcia ${ }^{2}$, Annelise Sepulveda ${ }^{2}$, Cecilia Tapia ${ }^{8}$, Luis Fernando Mallea ${ }^{9}$, Felipe Rivera ${ }^{1}$, Ezio Parodi ${ }^{10}$, Jyh Kae Nien ${ }^{5}$

${ }^{1}$ Department of Pulmonary Diseases, Clinica Davila, Santiago, Chile

${ }^{2}$ Adult Intensive Care Unit, Clinica Davila, Santiago, Chile

${ }^{3}$ Department of Epidemiology, School of Nurse and Midwifery, Universidad de los Andes, Santiago, Chile

${ }^{4}$ School of Medicine, Universidad de los Andes, Santiago, Chile

${ }^{5}$ Department of Medical Management, Clinica Davila, Santiago, Chile

${ }^{6}$ Department of Surgery, Surgical Pavilions, Clinica Davila, Santiago, Chile

${ }^{7}$ Emergency Service, Clinica Davila, Santiago, Chile

${ }^{8}$ Laboratory Service, Molecular Biology Section, Santiago, Chile

${ }^{9}$ Pediatric Intensive Care Unit, Clinica Davila, Santiago, Chile

${ }^{10}$ Ethics Committee, Clinica Davila, Santiago, Chile

\section{Email address:}

cmaquilon87@hotmail.com (C. M. Ortiz),jgongora@davila.cl (J. A. Gongora), antoliniventilados@gmail.com (M. A. Toledo), vonfer.qamb@gmail.com (N. F. Valdes), asbenavente@miuandes.cl (A. Benavente), mgbofill@miuandes.cl (M. G. Bofill), murra@miuandes.cl (M. Urra),dfrojas1@miuandes.cl (D. R. Carvajal), jihuidobro@miuandes.cl (J. H. Navarro), bernardita.alvarado@davila.cl (B. A. Breton), carolina.asenjo@davila.cl (M. C. Asenjo), cherie.gutierrez@davila.cl (C. G. Rojas), jose.gajardo@davila.cl (J. Gajardo), pcistern@davila.cl(P. Cisternas), guillermo.garcia@davila.cl (G. Garcia), jperalta@davila.cl (J. P. Peralta), lloor@davila.cl (L. L. Garcia), anneliese.sepulveda@davila.cl (A. Sepulveda), cvtapiap@gmail.com (C. Tapia), lmallea@davila.cl (L. F. Mallea), frivera@davila.cl (F. Rivera), eparodi@davila.cl (E. Parodi), jyh.nien@davila.cl (J. K. Nien)

${ }^{*}$ Corresponding author

\section{To cite this article:}

Cesar Maquilon Ortiz, Jonas Alberto Gongora, Monica Antolini Toledo, Nicolas Fernando Valdes, Angela Benavente, Maria Gabriela Bofill, Macarena Urra, Diego Rojas Carvajal, Javiera Huidobro Navarro, Bernardita Alvarado Breton, Maria Carolina Asenjo, Cherie Gutierrez Rojas $^{5}$, Jose Gajardo, Patricia Cisternas, Guillermo Garcia, Juan Pablo Peralta, Lenny Loor Garcia, Annelise Sepulveda, Cecilia Tapia, Luis Fernando Mallea, Felipe Rivera, Ezio Parodi, Jyh Kae Nien. Clinical and Demographic Characteristics on Admission and Their Prognostic Value at Discharge in 529 Consecutive COVID-19 Patients in Santiago, Chile. Clinical Medicine Research. Vol. 10, No. 1, 2021, pp. 1-8. doi: $10.11648 /$ j.cmr.20211001.11

Received: December 13, 2020; Accepted: December 28, 2020; Published: January 4, 2021

\footnotetext{
Abstract: On June 04, 2020, Chile had 113,628 cases COVID-19, 1275 deaths, 1450 patients were on invasive mechanical ventilation (IMV). The objective was describing the characteristics on admission and their relationship with the condition at discharge of patients with positive real-time polymerase chain reaction test for SARS CoV-2 (RT-PCR) in a tertiary health center. Methods: Retrospective and observational cohort study of 529 consecutive patients with positive RT-PCR for SARS CoV-2, discharged between March 14 and June 4, 2020 from Clinica Davila, Santiago. Demographic data, laboratory tests, Quality Adjusted Life Years (QALY), medical insurance, ventilatory assistance, and discharge condition were collected. Differences were
} 
evaluated by chi-square test, student's $t$ test, or Mann-Whitney U test. Logistic regression analysis was performed to identify variables that were predictive of condition at discharge. Results: A total of 529 patients were included (median age, 49 years [interquartile range $\{\mathrm{IQR}\}, 37-62$; range, 0-97 years]; 45\% women). The most common comorbidities were hypertension (171, $32.3 \%$ ) and diabetes mellitus $(98,18.5 \%)$, On admission 352 patients $(66.5 \%)$ had respiratory symptoms and $177(33.4 \%)$ had other symptoms or other diagnoses. The median (IQR) $\mathrm{PaO}_{2} / \mathrm{FiO}_{2}$ on admission of survivors, non-survivors and transferred were 316 (261-360), $167(80-268)$ and 212 (130-261) respectively. At discharge, 448 (84.7\%) were survivors, 54 (10.2\%) nonsurvivors, and 27 (5.1\%) were transferred to other centers. Median age of survivors and non-survivors was 46 (36-59) and 75.5 (66-84) years. Of the 116 patients $(21,9 \%)$ who received support ventilation, 67 were discharged alive $(57.8 \%), 28$ died (24\%), and $21(18 \%)$ were transferred to another hospital. The variables associated with risk of death were: age $\geq 60$ years (OR 15.3; 95\% CI: 7.25-32.2; $\mathrm{P}=0.001)$; QALY score $\leq 15$ points (OR 14.01; 95\% CI: $4.82-40.67 ; \mathrm{P}=0.001)$; state health insurance (OR, 2.82; 95\% CI: 1.38-5.77; $\mathrm{P}=0.004) ; \mathrm{PaO}_{2} / \mathrm{FiO}_{2}$ on admission $\leq 200$ (OR 5.2; 95\% CI: 1.94-13.94; $\mathrm{P}=0.001$ ) and high sensitivity $\mathrm{T}$ Troponin $\geq 15 \mathrm{ng} / \mathrm{L}$ (OR 5.16; 95\% CI: 1.95-13.64; $\mathrm{P}=0.001$ ). Conclusions: this cohort showed that on admission COVID-19 patients, the $\mathrm{PaO}_{2} / \mathrm{FiO}_{2}$, creatinine and high sensitivity $\mathrm{T}$ troponin at the described cut-off points had prognostic value. At discharge, the non-survivors were the older, most often had state health insurance and their QALY scores were significantly lower.

Keywords: Coronavirus Infections, Quality Adjusted Life Years, Health Insurance, Pcr Sars CoV2, Prognostic Factors, COVID-19

\section{Introduction}

The first case of COVID-19 was reported in Chile on 3 March 2020. On June 04, 2020, Chile had 113,628 cases COVID-19, 1275 deaths, 1450 patients were on invasive mechanical ventilation (IMV) in intensive care unit (ICU) [1] On that date Clinica Davila had 529 patients discharged with positive SARS CoV-2 (RT-PCR). This private hospital is located in the northern area of Santiago, in the commune of Recoleta, it has 647 beds is the largest private hospital in Chile (Figures 1 and 2). Between April and June 2020, the hospitalizations of COVID-19 patients were increasing as well as the need to provide ventilatory support, this forced tripling the capacity of intensive care units, including the conversion of surgical wards for this purpose. The increase in the number of patients requiring hospitalization motivated to search for variables on admission that had prognostic value. Main objective was to describe the demographic, clinical and laboratory characteristics of patients with positive RT-PCR for SARS CoV-2 on admission and their prognostic value at discharged. According to global reports, $81 \%$ of COVID-19 infections are mild, $14 \%$ severe and 5\% require intensive care [2]. Mortality rates published by China, Italy and the United States range from 1.4\% among hospitalized patients to $61.5 \%$ among critically ill patients $[3,4]$.

\section{Patients and Methods}

\subsection{Subjects}

All adults and children of both sexes, consecutively discharged from Clinica Davila between March 14, 2020 and June 4, 2020, with a positive RT-PCR test for SARS CoV-2, were included in this study. Patients remained hospitalized for at least 24 hours at any of the Clinic's department. The sequence in which patients were discharged was in March, 6 patients; in April, 17 patients; in May, 452 patients and in the first 4 days of June, 54 patients.

\subsection{Ethical Issues and Informed Consent}

This study was conducted in accordance with the Helsinki Declaration [5] and was approved by the Davila Clinic Scientific and Ethics Committee.

\subsection{Study Design}

Retrospective and observational cohort study whose date were collected from the establishment's electronic clinical record (RCE) (www.tisal.cl); compiled into a database created for the study and designed to ensure that patients' identities were protected.

\subsection{Methods}

The diagnosis of COVID-19 was made according to World Health Organization (WHO) guidelines. Confirmed case samples were obtained from the upper respiratory tract by nasopharyngeal swab [6]; they were registered in the mandatory reporting system, Epivigila (https://epivigila.org.cl) [7], established by the Ministry of Health (MINSAL); were collected respiratory and nonrespiratory symptoms, sex, age, health insurance, duration of pre-entry symptoms and comorbidities: type 2 diabetes mellitus (DM2), high blood pressure (HTA), cancer, AIDS$\mathrm{HIV}$, immunosuppression for other causes, heart failure, renal failure, obesity, coronary heart disease, bronchial asthma, active smoking and chronic obstructive pulmonary disease; in addition, the results of laboratory on admission, hospital stay, ventilatory support (expressed in days), hospitalization unit and discharge condition (survivors, nonsurvivors or transfer to another institution), the data were obtained retrospectively from the RCE. Also, in all patients the Quality-Adjusted years of life (QALY) score was calculated, this score corresponds to a generic disease burden measurement used to assess the impact of therapeutic measures on expected survival quality with or without intervention [8-10]. QALY was calculated considering the 
life expectancy for men and women expressed in years $(80.5$ years) [11] and proceeded to use the following formula:

$$
[(80.5 \text { - age }) \times(1-X)] \text {, }
$$

being "X":

0 in case it had no comorbidity.

0.1 for each compensated comorbidity.

0.2 for each decompensated comorbidity,

0.3 in case of bedridden patient

\subsection{Process Description Sampling, Ethological Agent and Laboratory Tests}

Laboratory tests on admission were performed in the emergency room or within the first 3 hours of admission, including:

Real-time PCR viral panel (identifying seventeen viruses), real-time PCR bacterial panel (identifying seven bacteria), urinary antigen for Pneumococcus and Legionella, blood cultures and expectoration cultures.

Arterial blood sample for gases, calculation of the relationship between partial blood pressure of $\mathrm{O}_{2}$ and the fraction of $\mathrm{O}_{2}$ that the patient was receiving at the time of sample collection $\left(\mathrm{PaO}_{2} / \mathrm{FiO}_{2}\right)$, serum ferritin levels, Double dimer (D-dimer), C-reactive protein (PCR), creatinine, high sensitivity $\mathrm{T}$ troponin, procalcitonin, hematocrit, platelet count and leukocyte count.

The $\mathrm{PaO}_{2} / \mathrm{FiO}_{2}$ obtained before the start of ventilatory support was also recorded in the database.

\subsection{Methods of Oxygen Administration and Ventilatory Support Used}

The $\mathrm{O}_{2}$ administration was carried out as follows

1. Low flow nasal cannula (maximum flow $4 \mathrm{~L} / \mathrm{min}$ ).

2. High flow ventilation mask $\left(\mathrm{FiO}_{2}\right.$ between $40 \%$ and $50 \%)$.

3. Non-recirculation mask $\left(\mathrm{FiO}_{2}\right.$ between $50 \%$ and $\left.90 \%\right)$.

4. High Flow Nasal Cannula (HFNC)

5. Non-invasive mechanical ventilation (NIMV)

6. IMV.

The devices used were as follows:

HFNC: AIRVO 2 (Fisher \& Paykel, Nueva Zelanda).

NIMV: Philips Respironics V60, BiPAP Vision, Trilogy 100 and Trilogy 202.

IMV: Avea, Vela, Bellavista (VYAIRE Medical, INC), Engstrom Carestation (General Electric), MAQUET (Getinge Group), Nellcor Puritan Bennett 840 (Medtronic) and GE Datex Ohmeda Aestiva 5 (General Electric) anesthesia machines.

\subsection{Statistical Analysis}

Quantitative variables were described by means of averages and standard deviation (for those with normal distribution) and with median and inter quarterly range $(\mathrm{Q} 1$, Q3) (for those without normal distribution). Categorical variables were described by absolute and relative frequencies; For categorical variables, the association with the discharge condition was evaluated by the chi-square test, while for quantitative variables, the association was evaluated by the student t-test (normal distribution) or the Mann-Whitney Utest (non-normal distribution). To assess risk factors at discharge univariate and multivariate logistic regression models were used. First, the variables were analyzed individually; those with a p-value less than 0.1 were incorporated into a staggered model with "direct selection" and variables with a Pearson correlation greater than 0.8 were excluded to avoid collinearity and choose variables with higher predictive capacity. Finally, univariate models were used with variables categorized according to clinical criteria, variables with a p-value less than 0.1 were re-incorporated into a staggered model. Significance level $(\alpha)$ less than or equal to 0.05 . All analyses were performed using STATA v14.2 IC (StataCorp) software. LLC, USA.

\section{Results}

\subsection{General Characteristics, Duration of Symptoms and Cause of Admission}

The median age (Q1, Q3) was 49 (37 - 62) years; 45\% were women, 353 patients $(68.5 \%)$ were under the age of 50 , 68 patients $(13 \%)$ were 70 years of age or older and $14(2.6 \%)$ were minors (Table 1). Of the cohort, 171 patients $(32.3 \%)$ were hypertensive, 98 were diabetic $(18.5 \%), 86$ patients $(16.2 \%)$ obese (BMI> 29.9) and 21 patients (4\%) referred active smoking to income. The median QALY was 29.7 points $(16.8$ - 43.7) (Table 1). The median duration of symptoms before admission was 6 days $(3-8)$. Of the 529 patients, $352(66.5 \%)$ were hospitalized for respiratory symptoms and the remaining 177 patients $(33.4 \%)$, the reasons for hospitalization were other non-respiratory diagnoses or other symptoms, of these, 84 patients $(15.9 \%)$ had digestive symptoms (nausea, vomiting, diarrhea or abdominal pain), severe myalgias or headache that did not respond to outpatient treatment; $23(4.34 \%)$ entered for other concomitant infections (cholangitis, acute cholecystitis, acute pyelonephritis, or others) and 70 patients (13.2\%) for noninfectious causes (pregnancy, newborns, acute coronary syndrome, deep vein thromboembolism and others) (Table 1). In these cases, the diagnosis of SARS CoV-2 was performed by mandatory screening of RT-PCR prior to hospitalization.

\subsection{Global Lethality, Depending on Age, QALY, Respiratory Support, Health Insurance and Other Conditions}

At discharge 448 patients $(84.7 \%)$ were survivors, with a median age of 46 (36 - 59) years, and 54 non-survivors $(10.2 \%)$, with median age $75.5(66-84)$ years $(p=0.001)$ (Table 2$)$. Of the dead, 45 patients $(83.3 \%)$ were 60 years of age or older, with a lethality of $29 \%$ for the group of 60 years or older (Table 3 ). The QALY score of the survivors was 33 points (9.7 to 44.7$)$ and in non-survivors of 4.4 points $(-2.2$ to 12.3$)(\mathrm{p}=0.001)$. (Table 2$)$. The duration of hospitalization was 6 (4-10) days for the survivors on discharge and 6.5 (4-13) days for the non-survivors 
$(\mathrm{p}=0.337)$ (Table 2). Of the 529 patients, $177(33.45 \%)$ no oxygen or ventilatory support required, 236 (44.6\%) received oxygen at variable flows or High Flow Nasal Cannula (CNAF) and $116(21.9 \%)$ needed NIMV or IMV. None of the patients in this cohort underwent extracorporeal membrane oxygenation. The median (IQR) $\mathrm{PaO}_{2} / \mathrm{FiO}_{2}$ on admission of survivors, nonsurvivors and transferred were 316 (261-360), 167 (80-268) and 212 (130-261) respectively (Table 2). Of the 116 patients receiving IMV or NIMV, 67 were alive (57.8\%), 28 dead (24\%) and $21(18 \%)$ were transferred to another hospital. The transfer of patients to other centers was under the jurisdiction of MINSAL's Centralized Bed Management Unit (UGCC), which moved patients that did not have a bed available in the hospital where they consulted. In this cohort, 27 patients were transferred to other hospitals, including 21 patients directly to ICU beds available at other centers (Table 3). In relation to health insurance, 195 patients $(36.86 \%)$ had private health insurance, with an average age of $45 \pm 17.3$ years (range; 0 - 93) and only 38 patients $(19.4 \%)$ were 60 years old or older, in this group had private health insurance, 10 patients $(5.12 \%)$ died during hospitalization. On the other hand, 317 patients $(59.9 \%)$ belonged to state health insurance, the average age was $53.2 \pm 17.8$ years (range; 0 - 97), where 122 patients $(38 \%)$ they were 60 years old or older; In the group had state health insurance, 42 patients died (15.4\%) during hospitalization. When comparing patients belonging to the two types of health insurance, the difference in intrahospital lethality was significant $(p=0.001)$. The univariate analysis showed that having state health insurance increased the risk of death by 2.8 times (OR, 2,825; 95\% CI: 1,383 - 5,772; $\mathrm{P}=0.004)$.

\subsection{Univariate and Multivariate Logistic Analysis of Demographic Variables, Comorbidities and Laboratory}

In the univariate analysis, clinical and laboratory variables that showed significant differences between survivors and nonsurvivors to discharge were age, high blood pressure, diabetes, procalcitonin, ferritin, $\mathrm{PaO} 2 / \mathrm{FiO}_{2}$, leukocytes, d-dimer and creatinine. Based on the results of the published studies $[3,4,12-$ 14], cut-off points were applied for the demographic and laboratory variables obtained on admission and then their relationship to the discharge condition was analyzed. The univariate analysis of the categorized variables showed that the age $\geq 60$ years, QALY score $\leq 15$, D dimer $>1 \mathrm{ug} / \mathrm{ml}$, Highsensitive T Troponin $\geq 15 \mathrm{ng} / \mathrm{L}, \mathrm{C}$ Reactive Protein $(\mathrm{PCR})>8.2$ $\mathrm{mg} / \mathrm{dL}$, Procalcitonin $\geq 0.5 \mathrm{ng} / \mathrm{ml}$ and Creatinine $>1.4 \mathrm{mg} \%$ were associated with increased risk of death, while the multivariate analysis of these showed that the QALY score $\leq 15$ points, $\mathrm{PaO}_{2}$ / $\mathrm{FiO}_{2}$ on admission $\leq 200$ and Ultrasensitive $\mathrm{T}$ Troponin $\geq 15 \mathrm{ng} / \mathrm{L}$, were risk factors for death to discharge (Table 4).

\section{Discussion}

In our cohort the median age was 49 years and intrahospital lethality was $10.8 \%$. In a similar cohort, 393 consecutive cases, median age was 62.2 years (IQR; 48.6 73.7) with an overall lethality of $10.2 \%$ [14]. Other report of 5700 patients analyzed, the median age was 63 years (IQR; 52 - 75) with a range of 0 to 107 years (15). A study with 2215 patients who entered the ICU, the average age (SD) was 60.5 (14.5) years, at the end of this study $39.5 \%$ died and $54.3 \%$ were discharged [13]. In our cohort of the 116 patients receiving ventilatory support, the average age was 55.9 (14.1) years, $57.8 \%$ survivors and $24 \%$ deaths.

A study that described factors associated with death on admission to ICU, they found that older patients (age $\geq 80$ years versus $<40$ years of age; OR, 11.15; 95\% CI: 6.19 20.06) and the presence of hypoxemia $\left(\mathrm{PaO}_{2} / \mathrm{FiO}_{2}<100\right.$ vs $\geq 300 \mathrm{mmHg}$; OR, 2.94; 95\% CI: 2.11 - 4.08), were associated with a higher risk of death [13]. In our study the $\mathrm{PaO}_{2} / \mathrm{FiO}_{2}$ was quantified in all patients when they arrived at the emergency department. The cut-off point of less than or equal to 200 had a prognostic value of intra-hospital death.

The ventilatory support strategy used in the management of patients of the Clinica Davila cohort followed some of the recommendations given by J. C. Winck, N. Ambrosino and other authors [16, 17]. They suggest using CNAF in cases with mild respiratory failure $\left(\mathrm{PaO}_{2} / \mathrm{FiO}_{2}\right.$ between 200 and $300)$ and NIMV alone in patients with moderate respiratory failure $\left(\mathrm{PaO}_{2} / \mathrm{FiO}_{2}\right.$ between 100 and 200).

The QALY score [8-10] applied to hospitalized patients of our cohort at the cut-off point equal to or less than 15 points identify the patients with the highest risk of death, the calculation of this score has been implemented in the emergency service since March 2020. During the bibliographic review, no references were found to use this tool in COVID-19 patients. However other similar scores such as Charlson index [18] that consider age and similar comorbidities, predict life expectancy at 10 years, it has been use in a similar study [15]. Myocardial injury has been shown to be a common condition among COVID-19 hospitalized patients and has been associated with higher risk of in-hospital mortality in general populations [19, 20]. An Italian study evaluated the clinical outcomes of myocardial injury in patients with and without chronic coronary syndromes and COVID-19, they concluded that High sensitivity $\mathrm{T}$ troponin has a significant role in predicting poor outcomes [21]. In our cohort there were a significant difference when comparing the values on admission between survivors and non-survivors at discharge and in the multivariate analysis it maintained its significance compared to other parameters. In the cohort of Clínica Davila, this retrospective analysis showed that age, QALY score, $\mathrm{PaO}_{2}$ / $\mathrm{FiO}_{2}$, ultrasensitive $\mathrm{T}$ Troponin and creatinine at the described cut-off points, could be considered simultaneously and give rise to a severity score for COVID-19 patients. 


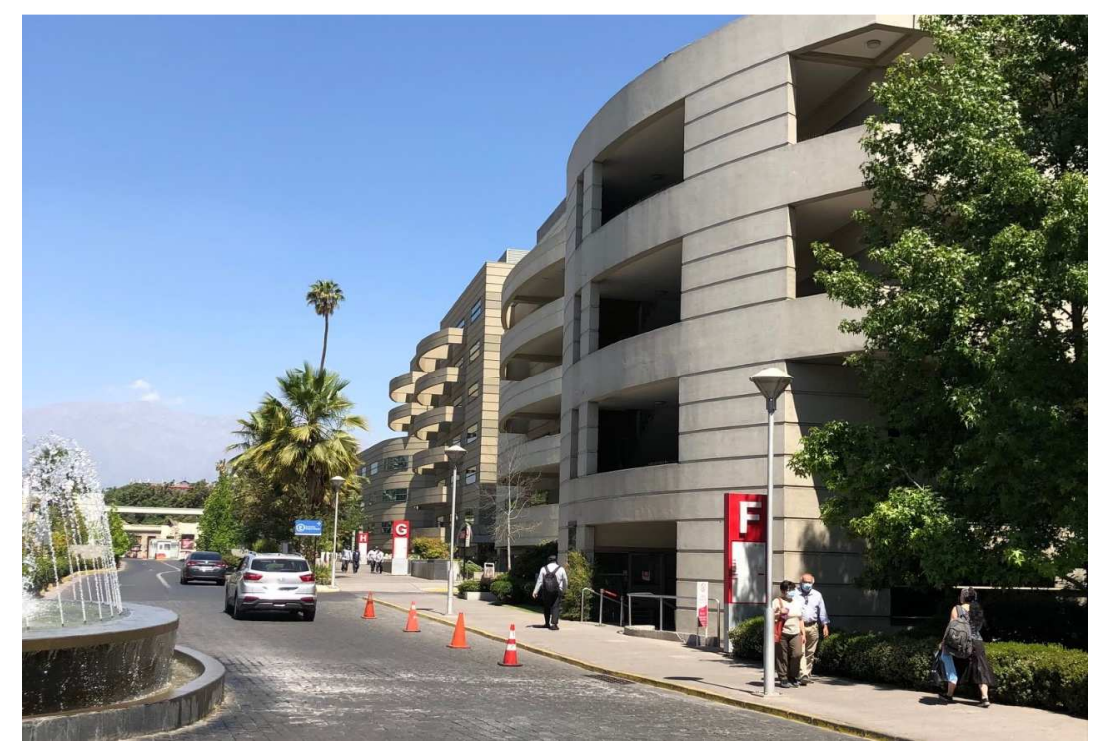

Figure 1. Clinica Davila has 647 beds is the largest private hospital in Chile.

Table 1. Demographic characteristics, symptoms, health insurance and laboratory on admission of patients with positive RT-PCR for SARS CoV-2. Clinica Davila (No. 529).

\begin{tabular}{|c|c|c|c|}
\hline \multicolumn{2}{|l|}{ Variables } & \multirow{2}{*}{$\begin{array}{l}\text { Absolute frequency/Average/ Median/ } \\
238\end{array}$} & \multirow{2}{*}{$\begin{array}{l}\begin{array}{l}\text { Relative frequency/Standard } \\
\text { deviation/RIQ* }\end{array} \\
45.0\end{array}$} \\
\hline Gender & Female & & \\
\hline & Male & 291 & 55.0 \\
\hline & $<18$ & 14 & 2.6 \\
\hline & $19-39$ & 151 & 28.5 \\
\hline \multirow{4}{*}{$\begin{array}{l}\text { Age range } \\
\text { (years) }\end{array}$} & $40-49$ & 102 & 19.3 \\
\hline & $50-59$ & 100 & 18.9 \\
\hline & $60-69$ & 94 & 17.8 \\
\hline & $\geq 70$ & 68 & 12.9 \\
\hline \multirow[t]{2}{*}{$\mathrm{BMI}^{\dagger}$} & $<30$ & 244 & 46.1 \\
\hline & $>29.9$ & 86 & 16.3 \\
\hline \multirow[t]{3}{*}{ Comorbidities } & Arterial Hypertension & 171 & 32.3 \\
\hline & Diabetes Mellitus & 98 & 18.5 \\
\hline & State health insurance & 317 & 59.9 \\
\hline \multirow[t]{4}{*}{ Health Insuranc } & Private health & 195 & 36.9 \\
\hline & Without health insurance & 17 & 3.2 \\
\hline & Symptoms respiratory & 352 & 66.5 \\
\hline & Digestive symptoms, myalgias, and headache & 84 & 15.9 \\
\hline \multirow{5}{*}{$\begin{array}{l}\text { Motive for } \\
\text { admission }\end{array}$} & obstetric gynaecological cause & 35 & 6.6 \\
\hline & Other infectious processes & 23 & 4.3 \\
\hline & Non-infectious processes & 32 & 6.0 \\
\hline & New-born & 3 & 0.6 \\
\hline & Age (years) & 49 & $(37-62)$ \\
\hline \multirow{7}{*}{ Conditions } & $\mathrm{QALY}^{\ddagger}$ score (points) & 27.7 & $(16.8-43.7)$ \\
\hline & Days with symptoms & 6 & $(3-8)$ \\
\hline & Days in hospital & 6.0 & $(3-10)$ \\
\hline & $\mathrm{PaO}_{2} / \mathrm{FiO}_{2}$ on admission & 304 & $(231-355)$ \\
\hline & $\mathrm{PaO}_{2} / \mathrm{FiO}_{2}$ pre $\mathrm{MV}^{\S}$ & 157.7 & 53.0 \\
\hline & Ferritin (ng/ml) & 785 & $(362-1524)$ \\
\hline & Double dimer $(\mu \mathrm{g} / \mathrm{ml})$ & 0.3 & $(0.2-0.6)$ \\
\hline \multirow{6}{*}{ Laboratory } & HS T troponin $(\mathrm{ng} / \mathrm{L})$ & 6.9 & $(4.4-12.5)$ \\
\hline & $\mathrm{CRP}(\mathrm{mg} / \mathrm{dl})$ & 7.1 & $(2.9-14.4)$ \\
\hline & Procalcitonin (ng/ml) & 0,1 & $(0.1-0.3)$ \\
\hline & Platelets, $\times 10^{9} / \mathrm{L}$ & 230 & $(180-295)$ \\
\hline & Leukocytes, $\times 10^{9} / \mathrm{L}$ & 7.4 & $(5.5-10.5)$ \\
\hline & Creatinine $(\mathrm{mg} \%)$ & 0.8 & $(0.7-1.0)$ \\
\hline
\end{tabular}

* Interquartile range.

$\dagger$ Body mass index expressed in $\mathrm{kg} / \mathrm{m}^{2}$.

$\$$ Quality-Adjusted life year.

$\S$ Mechanical Ventilation. 
Table 2. Demographic and laboratory characteristics, according to condition at discharge.

\begin{tabular}{|c|c|c|c|c|c|c|c|c|}
\hline & \multirow{3}{*}{ Category / Variable } & \multicolumn{2}{|l|}{ Survivors } & \multicolumn{2}{|c|}{ Non-survivors } & \multicolumn{2}{|l|}{ Transferred } & \multirow{3}{*}{ P value } \\
\hline & & $\begin{array}{l}\begin{array}{l}\text { Absolute } \\
\text { frequency }\end{array} \\
\end{array}$ & $\begin{array}{l}\text { Relative } \\
\text { frequency }\end{array}$ & $\begin{array}{l}\text { Absolute } \\
\text { frequency }\end{array}$ & $\begin{array}{l}\text { Relative } \\
\text { frequency }\end{array}$ & $\begin{array}{l}\text { Absolute } \\
\text { frequency }\end{array}$ & $\begin{array}{l}\text { Relative } \\
\text { frequency }\end{array}$ & \\
\hline & & Median & IQR* & Median & IQR* $^{*}$ & Median & IQR* & \\
\hline \multirow{4}{*}{ Characteristics } & $\mathrm{n}$ & 448 & 84.7 & 54 & 10.2 & 27 & 5.1 & - \\
\hline & Median age (IQR), years & 46 & $(36-59)$ & 75.5 & $(66-84)$ & 56 & $(39-61)$ & $<.001$ \\
\hline & $\mathrm{QALY}^{\dagger}$ score (points) & 33 & $(19.7-44.7)$ & 4.4 & $(-2.2-12.3)$ & 23.7 & $(18.2-37.5)$ & $<.001$ \\
\hline & Days with symptoms & 6 & $(3-8)$ & 5.0 & $(3-7)$ & 7.0 & $(5-10)$ & .80 \\
\hline \multirow{9}{*}{ Laboratory } & $\mathrm{PaO}_{2} / \mathrm{FiO}_{2}$ on admission & 316 & $(261-360)$ & 167 & $(80-268)$ & 212 & $(130-291)$ & $<.001$ \\
\hline & $\mathrm{PaO}_{2} / \mathrm{FiO}_{2}$ pre- mechanical ventilation & 148.0 & 47.0 & 127.7 & 62.7 & 103.2 & 46.2 & .09 \\
\hline & Ferritin $(\mathrm{ng} / \mathrm{ml})$ & 764 & $(337-1445)$ & 695 & $(399-2176)$ & 1060 & $(546-1875)$ & .46 \\
\hline & Double dimer $(\mu \mathrm{g} / \mathrm{ml})$ & 0.3 & $(0.2-0.5)$ & 0.8 & $(0.4-2.0)$ & 0.3 & $(0.2-0.6)$ & $<.001$ \\
\hline & High-sensitivity T troponin (ng/ml) & 5.8 & $(4.1-9.3)$ & 22.8 & $(15.1-44.9)$ & 7.3 & $(5.8-12.5)$ & $<.001$ \\
\hline & C-reactive protein $(\mathrm{mg} / \mathrm{dl})$ & 6.3 & $(2.3-13)$ & 13.9 & $(6.7-26.0)$ & 14.2 & $(6.1-24.6)$ & $<.001$ \\
\hline & Procalcitonin $(\mathrm{ng} / \mathrm{ml})$ & 0.1 & $(0.1-0.2)$ & 1.0 & $(0.3-1.8)$ & 0.2 & $(0.1-0.5)$ & $<.001$ \\
\hline & Leukocytes, $\times 10^{9} / \mathrm{L}$ & 7.2 & $(5.4-9.8)$ & 9.8 & $(6.5-14.7)$ & 7.7 & $(6.1-11)$ & $<.001$ \\
\hline & Creatinine $\left(\mathrm{mg}^{\circ} \%\right)$ & 0.8 & $(0.7-1.0)$ & 1.16 & $(0.8-1.8)$ & 0.8 & $(0.7-1.1)$ & $<.001$ \\
\hline
\end{tabular}

* Interquartile range.

$\uparrow$ Quality-Adjusted life year (QALY).

\section{SANTIAGO DE CHILE}

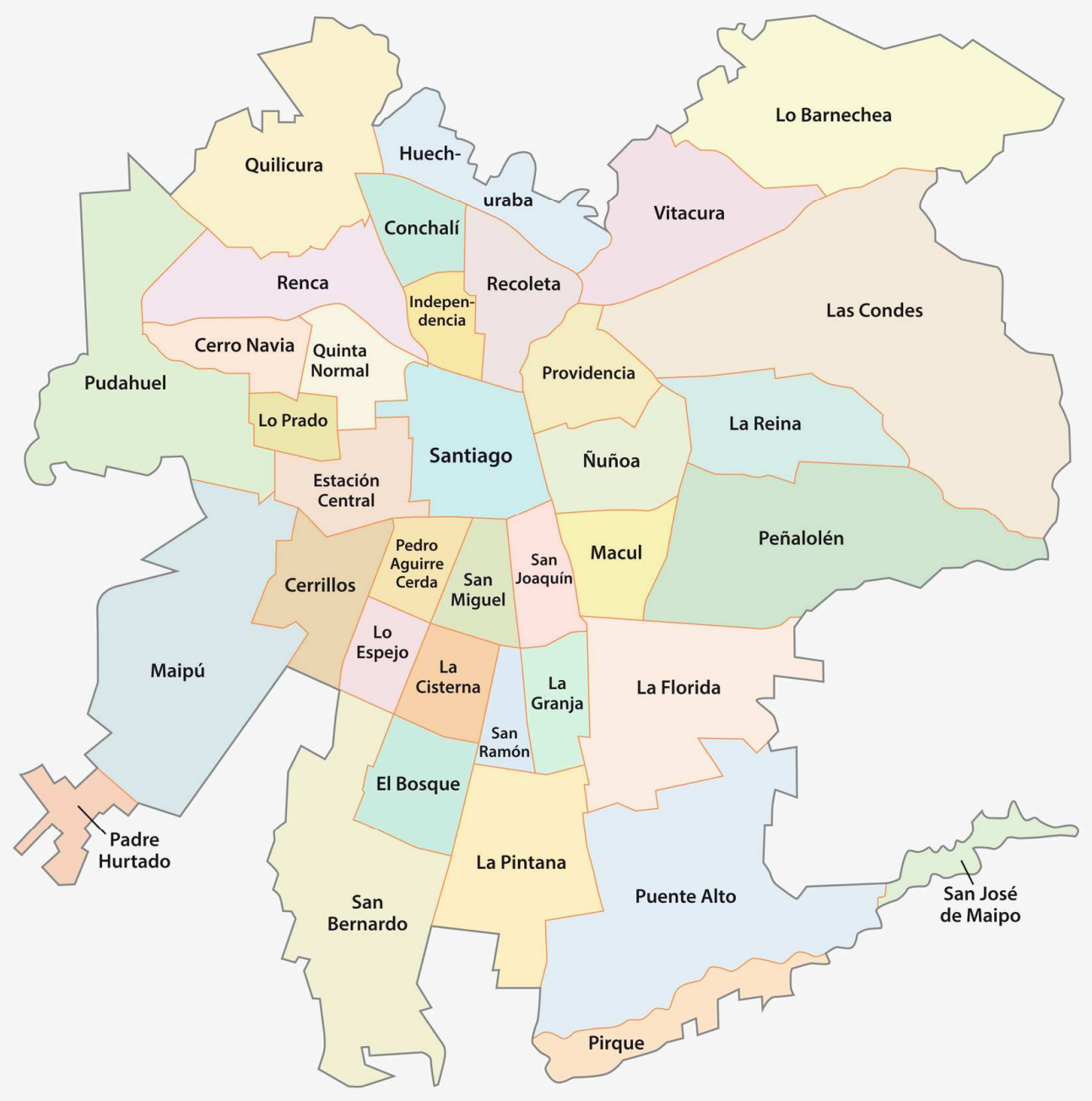

Figure 2. Davila Clinic is located in the northern area of Santiago, in the commune of Recoleta. 
Table 3. Demographics Characteristics, health insurance, motive for admission and last bed in the hospital, according to discharge condition.

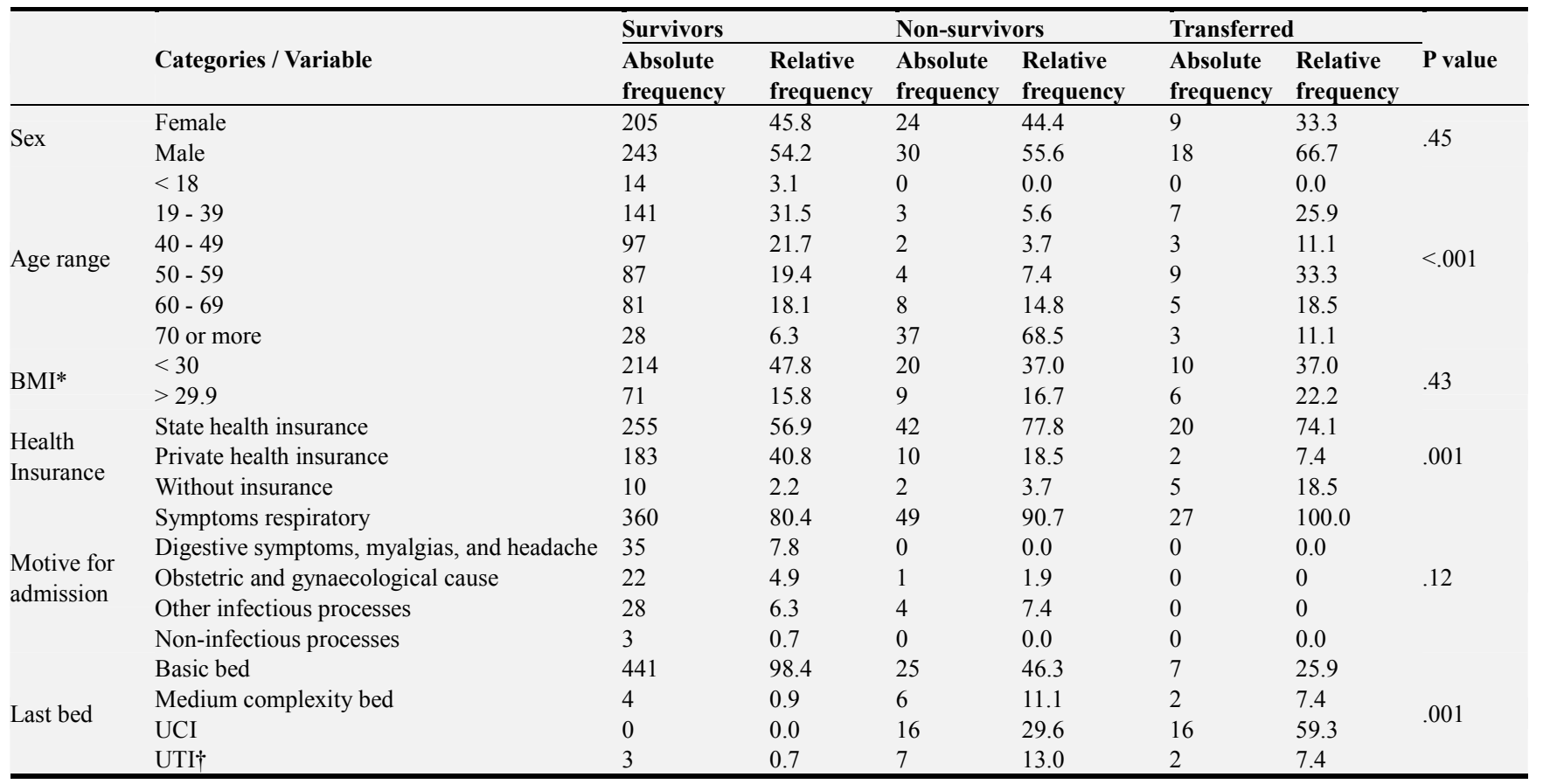

*Body mass index

$\dagger$ Intermediate Care Unit

Table 4. Univariate and multivariate logistic analysis of categorized variables.

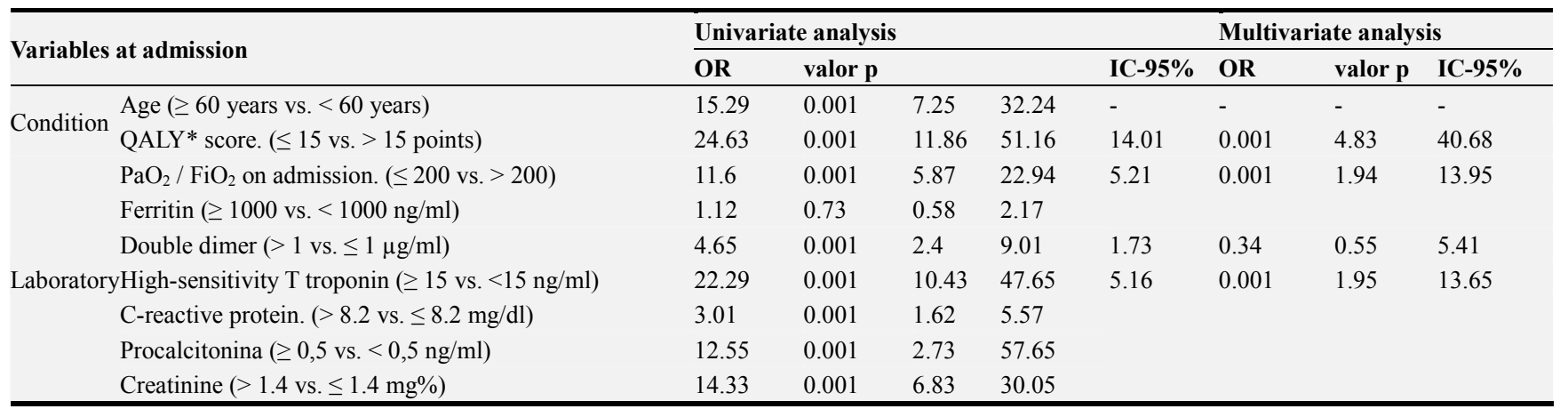

* Quality-Adjusted life year (QALY).

\section{Strengths and Limitations}

The strengths of this study were that it included Chilean population belonging to the two existing health systems, all patients were subjected to similar laboratory tests on admission and their management was governed by an operational committee that analyzed daily the flow of patients according to severity. Weaknesses were that due condition of severity of patients, the need for isolation as a very contagious disease, and the absence of relatives during their hospitalization may have weakened the complete collection of data referring to habits, and we did not report the final condition of 27 patients transferred to other centers.

\section{Conclusions}

These retrospective cohort, showed the demographics, clinics and laboratory characteristics on admission and their prognostic value in sequentially hospitalized patients with a positive RT-PCR test for SARS CoV-2 in a private hospital in the northern area of Santiago. In these 12 weeks were applied the indications that were released from the health authority and support therapies according to the severity of the patients, they were managed and hospitalized regardless of their health insurance. It was a useful description of a significant number of patients and their evolution, in addition the resulting variables at the cut-off points described, age $\geq 60$ years, the burden of prior diseases and age expressed in the QALY $\leq 15$, the moderate to severe respiratory compromise on admission quantified by $\mathrm{PaO}_{2} / \mathrm{FiO}_{2} \leq 200$, the degree of myocardial injury measure through an Ultra-sensitive $\mathrm{T}$ troponin $\geq 15$ $\mathrm{ng} / \mathrm{ml}$ and impaired kidney function present on admission and quantified through a creatinine $>1.4 \mathrm{mg} \%$, All the variables analyzed could contribute to other centers for 
decision-making or the design of gravity scales.

\section{Acknowledgements}

We thank all the 3100 employees of Davila Clinic and their families.

\section{References}

[1] https://www.diariooficial.interior.gob.cl/publicaciones/2020/0 6/04/42672/01/1769770.pdf

[2] https://www.diariooficial.interior.gob.cl/publicaciones/2020/0 6/04/42672/01/1769770.pdf Wu Z, McGoogan JM. Characteristics of and important lessons from the coronavirus disease 2019 (COVID-19) outbreak in China: summary of a report of 72314 cases from the Chinese Center for Disease Control and Prevention. JAMA. 2020, http://dx.doi.org/10.1001/jama.2020.2648 [Epub ahead of print].

[3] Guan WJ, Ni ZY, Hu Y, Liang WH, Ou CQ, He JX, et al. Clinical characteristics of coronavirus disease 2019 in China. N Engl J http://dx.doi.org/10.1056/NEJMoa2002032 [Epub ahead of print].

[4] Yang X, Yu Y, Xu J, Shu H, Xia J, Liu H, et al. Clinical course and outcomes of critically ill patients with SARSCoV-2 pneumonia in Wuhan, China: a single-centered, retrospective, observational study. Lancet Respir Med. 2020; 8 (5): 475-81.

[5] WMA - The World Medical Association- Declaration of Helsinki - Ethical principles for Medical Research involving Human Subjects [Internet]. [cited 2020 Jul 13]. Available from: https://www.wma.net/es/policies-post/declaracion-dehelsinki-de-la-amm-principios-eticos-para-lasinvestigaciones-medicas-en-seres-humanos/.

[6] Technical guidance [Internet]. [cited 2020 Jul 13]. Available from: https://www.who.int/emergencies/diseases/novelcoronavirus-2019/ technical guidance.

[7] Ingreso al sistema - SADEPI [Internet]. [cited 2020 Jul 13]. Available from: https://epivigila.minsal.cl/

[8] Quality-Adjusted life years and the devaluation of life with Disability: Part of the bioethics and disability series, National Council on Disability, November 6, 2019. www.ncd.gov.

[9] Haomiao Jia, Erica I. Lubetkin, John P. Barile, Willi HornerJohnson, Kimberly DeMichele, Debra S. Stark, Matthew M. Zack, William W. Thompson. Quality-adjusted Life Years (QALY) for 15 Chronic Conditions and Combinations of
Conditions Among US Adults Aged 65 and Older. Medical Care 2018; 56 (8): 740-746.

[10] Alvis N, Valenzuela M. T., Los QALYs y DALYs como indicadores sintéticos de salud. Rev Med Chile 2010; 138 (Supl 2): 83-87.

[11] www.ine.cl $>$ poblacion $>$ esperanza de vida.

[12] Grasselli G, Zangrillo A, Zanella A, Antonelli M, Cabrini L, Castelli A, et al. JAMA 2020 Apr 6; 323 (16): 1574-1581. Doi: $10.1001 /$ jama.2020.5394. Online ahead of print.

[13] Gupta S, Hayek S, Wang W, Chan L, Mathews K, Melamed $\mathrm{M}$, et al. Factors Associated with Death in Critically III Patients with Coronavirus Disease 2019 in the US. JAMA Intern Med. 2020 Jul 15; e203596. Doi: 10.1001/jamaintermed.2020.3596.

[14] Correspondence. Clinical Characteristics of COVID-19 in New York City. N Engl J Med 382; 24.

[15] Richardson S, Hirsch J, Narasimhan M, Crawford J, McGinn T, Davidson K, Presenting Characteristics, Comorbidities, and Outcomes Among 5700 Patients Hospitalized Witch COVID19 in the New York City Area. 2020; 323 (20): 2052-2059.

[16] Winck JC, Ambrosino N. COVID-19 pandemic and noninvasive respiratory management: Every Goliath needs a David. An evidence-based evaluation of problems. Pulmonology. 2020; 26 (4): 213-20

[17] Gattinoni L, Chiumello D, Caironi P, et al. COVID-19 pneumonia: different respiratory treatments for different phenotypes? Intensive Care Med. 2020; 46 (6): 1099-102.

[18] Charlson ME, Pompei P, Ales KL, MacKenzie CR.: A new method of classifying prognostic comorbidity in longitudinal studies: development and validation. J Chronic Dis 1987; 40 (5): 373-383.

[19] Shi, S.; Qin, M.; Shen, B.; Cai, Y.; Liu, T.; Yang, F.; Gong, W.; Liu, X.; Liang, J.; Zhao, Q.; et al. Association of Cardiac Injury with Mortality in Hospitalized Patients With COVID19 in Wuhan, China. JAMA Cardiol. 2020, 5, 802.

[20] Lala, A.; Johnson, K. W.; Januzzi, J. L.; Russak, A. J.; Paranjpe, I.; Richter, F.; Zhao, S.; Somani, S.; Van Vleck, T.; Vaid, A.; et al. Prevalence and Impact of Myocardial Injury in Patients Hospitalized With COVID-19 Infection. J. Am. Coll. Cardiol. 2020, 76, 533-546.

[21] Schiavone M, Gasperetti A, Mancone M, Kaplan A, Gobbi C, Mascioli G, Busana N, Saguner A, Mitacchione G, Giacomelli A, Sardella G, Viecca M, Duru F, Antonori S, Carugo S, Bartorelli A, Tondo C, Galli M, Fedele F and Forleo G B. Redefining the Prognostic Value of High-Sensitivity Trponin in COVID-19 Patients: The importance of Concomitant Coronary Artery Disease. J. Clin. Med. 2020, 9, 3263. 